\title{
DAMPAK YANG TIMBUL DARI PENCEKALAN DAN PENCEGAHAN KEIMIGRASIAN
}

\author{
I Komang Angga Bramandana ${ }^{(1)}$, M.Aliffashah ${ }^{(2)}$, Tresnadi Batavia $^{(3)}$ \\ 1,2,3Politeknik Imigrasi Badan Pengembangan Sumber Daya Manusia Hukum dan HAM RI. Indonesia \\ Email : Anggabramandana@gmail.com ${ }^{(1)}$, \\ aliffashah060516@gmail.com $^{(2)}, \underline{\text { Tresnadibatavia36@gmail.com }}^{(3)}$
}

\begin{abstract}
ABSTRAK
Ketetapan pada Undang-Undang Nomor 6 Tahun 2011 mengenai keimigrasian yang berhubungan terhadap pencegahan dan juga penangkalan, khususnya pencegahan dan penangkalan kepada Orang Asing, sejalan dengan kebijakan pemerintah pada bidang keimigrasian yang mana didasarkan pada asas "selective policy”,Kebijakan yang diatas dasarkan pada prinsip selektivitas. Menurut prinsip ini, hanya orang asing yang bisa membawa kesejahteraan rakyat, bangsa, dan negara Republik Indonesia yang tidak mengancam keamanan dan ketertiban dan juga tidak memusuhi rakyat atau negara kesatuan Republik Indonesia yang dapat masuk atau keluar wilayah Indonesia yang didasarkan pada Pancasila dan Undang-Undang Dasar 1945.

Kata Kunci: Kebijakan Selektif, Pencegahan, Penangkalan, Orang Asing
\end{abstract}

\begin{abstract}
Provisions in Law Number 6 Year 2011 regarding immigration relating to prevention and deterrence, especially prevention and deterrence of foreigners, are in line with government policies in the immigration sector which are based on the principle of "selective policy", the policy above is based on the principle of selectivity. . According to this principle, only foreigners who can bring the welfare of the people, nation and state of the Republic of Indonesia are not threatening security and order and are also not hostile to the people or the unitary state of the Republic of Indonesia who can enter or leave Indonesian territory based on Pancasila and the 1945 constitution
\end{abstract}

Keywords: Selective Policy, prevention, deterrence, Foreigners

\section{Pendahuluan}

\section{Latar Belakang}

Sebanyak 4.627 warga asing diberikan tindak administrative keimigrasian yaitu pendeportasian, penangkalan, denda, dan pembataan izin tinggal, sanksi ini diberikan oleh Direktorat Jenderal Imigrasi Selama tahun 2018.Direktur Jenderal Imigrasi Ronny Franky Sompie menyampaikan dari sekian ribu warga asing tersebut, Republik Rakyat Tiongkok menjadi penyumbang warga asing terbanyak. Sebanyak 299 warga tiongkok dikenakan TAK,Afganistan 270 orang, Vietnam 261 orang, dan Nigeria 253 orang.
Lalu ronny juga mengatakan terdapat sebanyak 147 warga malayasia yang dikenakan TAK yang membuat Malaysia berada pada urutan kelima. Bukan hanya pemberia TAK tapi penyidik keimigrasian juga memberikan hukan pidana pada 141 kasus. Selain itu, Ronny juga menyampaikan pihaknya sudah menunda penerbitan paspor kepada 5.785 TKI yang diduga akan menjadi TKI non prosedrual pada 125 kantor imigrasi.Seiring dilakukannya penangguhan penerbitan paspor kepada warga Indonesia yang diduga sebagai TKI nonprosedural, ada sebanyak 408 orang, yang keberangkatannya 
tertunda di 25 titik tempat pemeriksaan imigrasi (TPI) seluruh Indonesia.

Seperti yang telah dijelaskan pada Pasal 1 angka 1 Undang Undang Nomor 6 Tahun 2011 mengenai Keimigrasian tertera bahwa "Keimigrasian adalah hal ihwal lalu lintas orang masuk atau keluar wilayah Indonesia serta pengawasan dalam rangka menjaga tegaknya kedaulatan rakyat". Hal tersebut berhubungan dengan system pengawasan dan penindakan keimigrasian yang prosesnya melalui tahap pengecekan pencekalan setiap proses tersebut merrpakan salah satu pelaksanaan penegakan hokum. Jika kita mengkaji pada akibat yang akan ditimbulkan, pencekalan pencekalan karena fungsi keimigrasian ini menjadi tonggak awal bagi pemerintah suatu negara untuk menyaring seluruh orang dan aktivitas-nya baik warga negara asing (WNA) maupun warga negara indonesia (WNI) itu sendiri. Kenapa kita harus mengkaji dari ketentuan yang telah ditetapkan, karena larangan terhadap seseorang memiliki dasar hukum. Menurut pasal 16 undang-undang tersebut, larangan dapat dikenakan kepada siapa saja, terutama mereka yang telah digugat.Selain dalam UU keimigrasian, Pencekalan juga diatur dalam beberapa instrumen hukum di indonesia baik bersifat umum maupun khusus membahas terkait pencekalan yaitu seperti Peraturan Pemerintah Republik Indonesia Nomor 30 Tahun 1994 Tentang Tata Cara Pelaksanaan Pencegahan Dan Penangkalan.

Berdasarkan ketentuan keimigrasian yang bersifat universal, setiap negara memiliki kekuatan untuk mengotorisasi denganmenghalangi siapa pun yang boleh memasuki atau meninggalkan wilayah Indonesia. Warga negara asing yang ingin masuk ke suatu negara wajib memperlihatkan dokumen perjalanan kepada petugas imigrasi. Karena pengakuan universal ini, keberadaan ketentuan imigrasi merupakan kriteria yang sangat penting untuk pemeliharaan yurisdiksi yang dimana warga asing yang masuk ke suatu negara wajib tunduk terhadap peraturan yang ada pada negara. Pencegahan dan "Penangkalan adalah larangan yang bersifat sementara terhadap orang-orang tertentu untuk masuk ke wilayah Negara Republik Indonesia berdasarkan alasan tertentu" dijelaskan sebagaimana Peraturan Pemerintah Republik Indonesia Nomor 30 Tahun 1994 mengenai Tata Cara Pelaksanaan Pencegahan dan Penangkalan.

\section{Rumusan Masalah}

Dalam hal dilakukannya pengawasan terhadap orang asing di wilayah Indonesia imigrasi berkoordinasi dengan instansi terkait pengawasan terhadap orang asing ini. Maksud dari koordinasi bersama Instansi Pemerintahan lain Direktorat Jenderal Imigrasi membutuhkan bantuan dari instansi lain untuk mengawasi setiap kegiatan orang asing di Indonesia. Dalam proses tersebut maka pasti akan timbul beberapa pemersalahan, yang akan kita bahas lebih lanjut mengenai problematika yang sering terjadi. Problematika ini tidak boleh hanya dipandang sebagai masalah kependudukan atau demografi. Tetapi, hukum di indonesia juga harus ikut berkembang sesuai permasalah keimigrasian ini agar kedepannya indonesia tidak mengalami hal hal yang bersifat merusak kedaulatan bangsa ini. Oleh karena itu, imigrasi yang berfungsi sebagai penjaga pintu gerbang negara harus menngembangkan produk-produk hukumnya terkait pengawasan dan penindakan orang asing sepeti Kebijakan Pencekalan. Namun, apakah Imigrasi Indonesia mempunyai dasar hukum yang kuat untuk melakukan Pencekalan? Dan sudahkah kebijakan ini berjalan secara optimal? Serta bagaimana akibat hukum yang terjadi apabila dilakukan pencekalan?

\section{Tujuan Penelitian}

Tujuan dilakukannya penelitian ini guna mengetahui apa saja dampak yang timbul dengan dilakukannya pencegahan dan penangkalan serta apakah imigrasi telah 
mempunyai dasar yang kuat untuk dilakukannya pecekalan dan pencegahan tersebut

\section{Metode Penelitian}

Pada penelitian ini menggunakan metode dengan pendekatan kualitatif yang dimana metode kualitatif ini sebagai metode ilmiah yang sering digunakan oleh beberapa peneliti pada bidang ilmu seperti social, dan juga pendidikan. Penelitian kualitatif digunakan untuk membangun pengetahuan melalui pemahaman dan penemuan. Pendekatan penelitian kualitatif merupakan suatu proses penelitian dan pemahaman yang berdasarkan pada metode menyelidik suatu fenomena social dan masalah manusia.

\section{Pembahasan}

Pejabat Imigrasi adalah petugas imigrasi yang memberikan tanda masuk atau keluar pada dokjal WNI ataupun WNA, Orang yang dicurigai dapat memberikan dampak buruk dan berbahaya bagi keamana dan ketertiban umum dapat dikenai tindakan administrative keimigrasian. Berdasarkan definisi di atas, ruang lingkup tanggung jawab dan fungsi keimigrasian berkaitan dengan berbagai bidang seperti politik, ekonomi, sosial budaya, keamanan dan kependudukan.Dalam konteks pertumbuhan dan mobilitas manusia yang terus meningkat, peran serta fungsi keimigrasian merupakan elemen penting dan strategis untuk meminimalisir dampak negatif yang mungkin timbul dari kedatangan orang asing ke wilayah Indonesia. Untuk menggambarkan secara jelas peran operasional keimigrasian dalam pembahasan tindakan administratif keimigrasian, perlu dipahami landasan teori yang mendasari yaitu pengakuan masyarakat internasional atas hak eksklusif masing-masing negara., yang disebut dengan kedaulatan negara.Konsep kedaulatan menyiratkan bahwa negara memiliki semua kekuasaan untuk melaksanakan hak teritorialnya di dalam wilayah negara masing-masing. Hal inilah yang membuat pihak imigrasi wajib menindak WNA yang masuk ke Indonesia. Sesuai dengan konsep kedaulatan teritorial negara, paspor digunakan saat melintasi perbatasan antar negara.

Makna undang-undang keimigrasian dapat digunakan sebagai pedoman atau arah yang mengatur orang ke dalam dan ke luar Indonesia serta pengawasan kepada orang asing di Indonesia. Hukum imigrasi juga termasuk hukum publik, yang mengatur hubungan antara manusia dan negara (pemerintah). Keterkaitan antara kepentingan publik dan masalah keimigrasian yang bersinggungan dengan aspek pendekatan keamanan publik dan aspek pendekatan jaminan sosial, berarti undang-undang keimigrasian bukanlah hukum administratif umum. Meskipun termasuk dalam hukum administratif, namun karena keimigrasian terkait dengan beberapa aspek strategis, yang terpenting keimigrasian merupakan aspek menjaga kedaulatan negara, oleh karena itu untuk memastikan kepatuhan terhadap undang-undang keimigrasian diperlukan sanksi pidana khusus. Selain undang-undang yang ada, seperti undang-undang administratif lainnya, dan jika dibandingkan dengan sanksi lain yang lebih ringan untuk pelanggaran hokum administratif, posisi strategis fungsi keimigrasian secara rasional dapat dijadikan alasan.

Hukum imigrasi Indonesia mengikuti prinsip selective policy. Menurut prinsip ini, cuma orang asing yang bisa menjamin kesejahteraan rakyat, bangsa dan negara Republik Indonesia yang tidak mengancam keamanan dan ketertiban serta tidak memusuhi rakyat ataupun negara Indonesia yang bisa masuk atau keluar wilayah Indonesia. Warga negara asing dapat ditolak untuk sementara waktu masuk ke wilayah Indonesia karena alasan tertentu, misal alasan permusuhan terhadap penduduk dan Negara Kesatuan Republik Indonesia. Selain itu, sesuai dengan kebijakan selektif, izin tinggal dapat diberikan secara selektif pada orang asing tergantung dari maksud dan tujuan 
tinggal di Indonesia. Prinsip setiap warga negara Indonesia berhak keluar atau masuk wilayah Indonesia. Namun tidak berarti hakhak ini tidak dapat dibatasi. Untuk alasan tertentu dan untuk jangka waktu tertentu, warga negara Indonesia dapat dilarang keluar dari wilayah Indonesia dan dapat dilarang memasuki wilayah Indonesia. Namun, karena penangkal yang terutama ditujukan pada orang asing, pencegah terhadap warga negara Indonesia hanya bergantung pada keadaan yang sangat darurat atau khusus.

Dalam pelaksanaan Tri Fungsi Imigrasi, yakni sebagai PeIayan Masyarakat, Penegakan Hukum dan Keamanan Negara yang dalam pelaksanaannya harus berjalan dengan selaras, serasi dan seimbang baik daIam hal kegiatan teknis substansif maupun dalam hal administratif. Salah satunya seperti "kebijakan selektif keimigrasian" yang bertujuan menyaring orang asing yang mempunyai manfaat bagi indonesia dan tidak membahayakan keamanan negara, tidak menganggu ketertiban umum, serta sesuai dengan maksud dan tujuannya berada di wilayah indonesia. Kebijakan selektif keimigrasian ini direalisasikan salah satunya dalam bentuk Pencegahan dan Penangkalan (Pencekalan).

Nama orang-orang yang pantas untuk dilarang masuk atau keluari Indonesia baik warga negara Indonesia maupun orang asing yang diduga terlibat dalam masalah hukum, sehingga harus dilakukan pencegahan dan penangkalan keimigrasian. Pencegahan dan penangkalan adalah kewenangan khusus yang diberlakukan oleh undang-undang keimigrasian untuk mencegah siapa pun meninggalkan Indonesia dan untuk menangkal siapa pun memasuki Indonesia. Pelaksanaan pencegahan dan penangkalan terutama didasarkan pada alasan tertentu, dan beberapa di antaranya terkait dengan pertimbangan untuk melindungi kepentingan nasional.
Definisi Pencekalan

Pencekalan merupakan akronim dari Pencegahan dan Penangkalan yang biasa dipakai dalam dunia keimigrasian. Pencegahan sendiri berdasarkan UU no. 6 tahun 2011 tentang keimigrasian adalah adalah "larangan yang bersifat sementara terhadap orang-orang tertentu untuk keluar dari wilayah Indonesia berdasarkan alasan keimigrasian atau alasan lain". Orang-orang tertentu yang dimaksudkan disini, bukan saja orang asing tetapi juga warga negara Indonesia yang berada di luar wilayah Indonesia. Alasan keimigrasian merupakan hak khusus oleh pihak imigrasi suatu negara dalam rangka menjaga tegaknya kedaulatan negara. Hal ini sama seperti kasus dari Ustad Somad yang ditolak masuk ke Hongkong karena alasan yang tidak dipublikasikan. Hal ini tidak dapat dikatakan salah karena itu merupakan hak mereka dalam mejalankan negaranya baik karena alasan menjaga rahasia negara mereka ataupun alasan lain yang tidak layak diketahui oleh khalayak umum.

Permintaan penangkalan dapat diajukan oleh beberapa instansi pemerintahan terkait yang mempunyai kepentingan untuk menegakkan tugas dan fungsi masing-masing. Menteri melaksanakan Pencegahan berdasarkan.

a. Hasil dari pengawasan Keimigrasian serta hasil dari Tindakan Administratif Keimigrasian.

b. Ketertapan Menkeu dan Jaksa Agung sesuai dengan tugasnya masing-masing dan ketentuan peraturan yang berlaku.

c. Permintaan Kapolro sesuai dengan ketentuan peraturan yang berlaku.

d. Permintaan Ketua KPK sesuai dengan keterntuan peraturan yang belaku.

e. Permintaan Kepala BNN sesuai dengan ketentuan peraturan yang berlaku.

f. Permintaan pimpinan kementerian/lembaga lain yang berdasarkan undang-undang memiliki kewenangan Pencegahan. 
Beberapa instansi diatas melakukan pencegahan dengan alasan yang bersifat keimigrasian, terkait piutang negara, perkara pidana, serta pemeliharaan pertahanan dan keamanan negara.

Jika objek dari pencegahan adalah warga negara indonesia (WNI), maka penangkalan adalah warga negara asing (WNA). Penangkalan dalam pelaksanaanya harus memerlukan koordinasi dan sinergitas dari seluruh pihak yang terkait baik dari pemerintah indonesia sebagai negara tujuannya maupun negara asal orang asing tersebut.

Untuk penangkalan kepada warga negara asing dilakukan dikarenakan adanya dugaan mereka terlibat dalam sindikat kejahatan internasional dan diduga akan melakukan pencemaran nama baik indonesia. Sedangkan warga negara Indonesia dapat pula ditangkal, namun, kewewenangan dan tanggung jawab penangkalan terhadap warganegara Indonesia harusiidilakukan olehiibeberapa instansi yang kurang lebih sama dengan instansi yang berwenang melakukan pencegahan.

\section{Konsenterasi Pencekalan}

Pada Hakikatnya cekal adalah upaya pembatasan pada hak asasi manusia, namun karena bertentangan dengan prinsip Internasional setiap orang memiliki hak untuk melakukan perjalanan keluar maupun masuk wilayah suatu negara. Hal tersebut tertuang dalam Konvensi Internasional yang memuat hak asasi pribadi (personal right) bahwa "setiap orang berhak untuk berpindahpindah tempat. Namun seiring dengan perubahan aspek ketatanegaraan, termasuk amandemen konstitusi dan ratifikasi sejumlah perjanjian internasional hukum positif Indonesia, konsep cekal telah mengalami perubahan yang cukup signifikan, terutama yang berkaitan dengan hak asasi manusia.

Dewasa ini banyak kebijakankebujakan baru yang bermunculan dengan mengatasnamakan penegakkan HAM. Bukan berarti hal ini salah, melainkan pembiaran akan kebijakan-kebijkan tersebut dapat memunculkan suatu niat dari oknum yang tidak bertanggung jawab dalam memanfaatkan momentum ini untuk memecah belah kesatuan indonesia dan menggangu kesejahteraan hidup bangsa indonesia. Pengungsi merupakan salah satu contoh penegakkan hak asasi manusia yang mengenyampingkan hukum positif indonesia. Pengungsi juga tidak dapat difilter karena bersifat situasional dan sesegera mungkin memerlukan suaka dari negara tujuannya. Dan tidak sempat dilakukan proses pencekalan oleh pihak imigrasi atau sejenisnya di negara tersebut. Oleh karena itu, pencekalan harus dibuat jelas dasar hukumnya dan pelaksanaanya dimaksimalkan secara menyeluruh di seluruh tempat pemeriksaan imigrasi (TPI) yang ada di indonesia.

Pencekalan harus diputuskan dalam keputusan tertulis yang mempunyai kekuatan hukum yang kuat dan bersifat fleksibel. Artinya, proses pencekalan dapat dilakukan sesuai prosedur yang telah di undangundagkan dan juga harus bersifat situasional. Situasional disini bermaksud agar pencekalan dapat dilakukan ditempat jika terdapat bukti yang menguatkan pencekalan tersebut serta tanpa melakukan pemberitahuan. Apakah tindakan ini digolongkan tindakan melawan hukum? Tidak, karena pencekalan yang dilakukan oleh petugas imigrasi sekali lagi terkait dengan kedaulatan negara indonesia. Tetapi, untuk mewujudkan adanya kebijakan tersebut, perlu adanya suatu dasar hukum baru yang harus ditetapkan dan penguatan hak-hak istimewa yang telah dimiliki oleh imigrasi. Karena, sering terdapat berbagai kasus dari beberapa pihak yang dirugikan oleh hak istimewa imigrasi ini menentang kewenangan imigrasi dalam hal tersebut.

Prespektif hukum mengenai pencekalan yang dilakukan imigrasi menghasilkan beberapa pandangan dari berbagai aspek-aspek di kehidupan 
bermasyarakat, berbangsa, dan bernegara. Beberapa tafsiran dibawah ini merupakan garis besar terhadap kebijakan imigrasi di indonesia. Berikut adalah unsur-unsur hukum yang terdapat pada kegiatan pencekalan beserta penjelasan dan contohnya.

a. Subjek Hukum Dalam Pencekalan

Dalam pelaksanaan pencekalan, terdapat beberapa subjek hukum yang dilahirkan. Pertama, pihak yang melakukan pencekalan dalam hal ini adalah Petugas Imigrasi setelah ditetapkan oleh Direktorat Jenderal Imigrasi dan permintaan dari Kepolisan Negara Republik Indonesia, Menteri Keuangan, Jaksa Agung, Komisi Pemberantasan Korupsi, Kepala Badan Narkotika Nasional, serta instansi lain yang berwenang mengajukan pencekalan. Intansiinstansi diatas berstatus sebagai subjek hukum karena mempunyai hak dalam mencekal setiap orang yang bertentangan dengan hukum positif indonesia. Kedua. Orang yang dicekal yang terdiri dari warga negara indonesia dan warga negara asing. Kedua subjek diatas dikatakan sebagai subjek hukum karena memiliki hak dan kewajiban terkait alasan dia dicekal. Ketika akan datang ke Indonesia setiap orang asing memiliki hak. Mereka memiliki hak-hak perdata yang dijamin oleh undang-undang. Hak bagi warga negara indonesia tentunya lebih banyak dari orang asing itu sendiri.

b. Objek Hukum Atas Pencekalan

Lalu lintas dan pengawasan terhadap WNA dan WNI merupakan objek hukum yang dihasilkan akibat proses pencekalan. Dalam menangani keluar masuknya orang asing ataupun WNI Ditjenim menjadi institusi yang pertama yang bertanggung jawab akan hal ini. Ini tidak terlepas dari pada tugas dan kewajibannya dalam rangka menunjang sekuriti nasionaliidi bidang keimigrasian. Arti pengawasan yang luas ini menjadikan subjek hukum terkait pencekaln ini semakin bertambah banyak karena tidak hanya dalam lingkup pencekalan pada saat melewati tempat pemeriksaan keimigrasian (immigration checkpoint). Tetapi juga, merambat sampai ke akar-akarnya. Dimulai dari pengajuan dokumen keimigrasian seperti paspor, visa, maupun izin tinggal serta alih status. Alasan ini dilakukan karena memang diperlukan agar mencegah kejahatan sedini mungkin dan memang hal ini juga ditetapkan di UU Keimigrasian yaitu Pasal 67 UU nomor 6 tahun 2011 yang berbunyi "Pengawasan Keimigrasian terhadap warga negara Indonesia dilaksanakan pada saat permohonan Dokumen Perjalanan, keluaratau masuk, atau berada di luar Wilayah Indonesia".

c. Akibat Hukum Atas Pencekalan

Akibat hukum yang timbul terhadap proses pencegahan dan penangkalan kwpada WNA dan WNI berdasarkan paparan sebelumnya, tindakan tersebut dapat diberikan sanksi administratif keimigrasian dan sanksi pidana yang penerapannya telah sesuai dengan Undang-Undang Nomor 6 Tahun 2011 tentang Imigrasi apabila WNA/WNI tersebut melakukan tindak pidana. Pengawasan dan Tindakan Keimigrasian terhadap WNA Menurut Undang-undang mengenai Keimigrasian, Pengawasan orang asing di Indonesia mencakup: Masuk serta keluarnya orang asing dari wilayah Indonesia serta Keberadaan dan kegiatan orang asing di wilayah Indonesia. Begitu pula warga negara indonesia yang mengajukan pembuatan Dokumen Perjalanan, harus diawasi dari awal tujuan dan maksudnya ke luar negeri dan aktivitas selama dia berada disana sampai kepulangannya ke indonesia harus dilakukan pengawasan salah satu bentuknya adalah pencekalan. Baik dilakukan sebelum dia keluar negeri dengan pencantuman dalam daftar pencegahan maupun penangkalan apabila yang bersangkutan akan masuk ke wilayah indonesia kembali.

d. Dampak Hukum Atas Pencekalan

Penegakan hukum bukanlah suatu kegiatan yang berdiri sendiri, melainkan mempunyai hubungan timbal-balik yang erat dengan masyarakatnya. Penegakan hukum dalam suatu masyarakat mempunyai 
kecenderungan-kecenderungannya sendiri yang disebabkan oleh struktur masyarakatnya. Struktur masyarakat ini merupakan kendala, baik berupa penyediaan sarana sosial yang memungkinkan penegakan hukum itu dijalankan., maupun memberikan hambatan-hambatan yang menyebabkan ia tidak dapat diajalankan atau kurang dapat dijalankan dengan seksama. Menurut Satjipto Raharjo penegakan hukum pada hakikatnya merupakan penegakan ideide atau konsep-konsep tentang keadilan, kebenaran, kemanfaatan sosial dan sebagainya. Jadi penegakan hukum merupakan usaha untuk mewujudkan ide dan konsep-konsep tadi menjadi kenyataan. Sehingga upaya penegakan hukum melalui pencekalan sering berdampak pada pertentangan hukum positif di indonesia.

Seperti Pasal 16 ayat (1) huruf b UU Keimigrasian yang sering dikatakan bertentangan. Padahal, pasal ini tidak bertentangan dengan konstitusi. hak bergerak atau cekal ini merupakan salah satu hak yang bisa dikurangi/dibatasi (derogable right) dengan undang-undang sebagaimana diatur Pasal 28I ayat (1) jo Pasal 28J ayat (2) UUD 1945. Cekal seperti diatur Pasal 16 ayat (1) huruf $\mathrm{b}$ itu merupakan pembatasan hak yang konstitusional. Aturan ini juga tercermin dalam Pasal 70 UU No. 39 Tahun 1999 tentang HAM yang menjamin hak bergerak, tetapi hak itu bisa dikurangi sepanjang diatur dalam undang-undang.

Instansi yang paling sering melakukan permintaan pencekalan ada komisi pemberantasan korupsi (KPK) tentunya mempunyai beberapa dasar hukum untuk merealisasikan wewenang tersebut. Landasan hukum KPK yang pertama, mengacu pada Undang-Undang KPK Nomor 30 Tahun 2002 Pasal 12 Ayat (1) huruf b yang berisikan, memerintahkan kepada instansi yang terkait untuk melarang seseorang bepergian ke luar negeri baik dari tingkat penyelidikan, penyidikan sampai penuntutan. Kemudian, Undang-Undang Imigrasi Nomor 6 Tahun 2011 diatur dalam
BAB IX tentang Pencegahan dan Penangkalan sesuai Pasal 91 sampai Pasal 103. Dalam Pasal 91 Ayat (2), berisikan, menteri dapat melaksanakan pencegahan berdasarkan, perintah Ketua KPK sesuai dengan ketentuan perundang-undangan yang berlaku. Bukan hanya itu, Pelaksanaan Pencegahan dan Penangkalan UndangUndang Imigrasi Nomor 6 Tahun 2011 diatur lebih lanjut dengan Peraturan Pemerintah Nomor 31 Tahun 2013 dalam Pasal 226 Ayat (2).

Selanjutnya, mengacu pada putusan Mahkamah Konstitusi (MK) dengan Nomor putusan 64/PUU-IX/2011 tentang Perkara Pengujian Undang-Undang Nomor 6 Tahun 2011 berkaitan Keimigrasian terhadap UUD Negara RI menyatakan bahwa putusan tersebut tidak mengurangi kewenangan KPK. Beberapa dasar hukum diatas memberikan kekuatan hukum yang konkrit akan pelaksanaan wewenang KPK sebagai salah satu instansi untuk mengajukan pencekalan kepada pihak imigrasi karena pencekalan bagi seseorang tersebut merupakan tindakan penting dalam menghalau koruptor untuk melarikan di ke luar negeri.

e. Upaya Melawan Cekal

Selama ini, upaya hukum yang sering dilakukan untuk melawan cekal adalah menggugat ke PTUN tempat pejabat yang mengeluarkan penetapan tertulis itu berada. Hampir semua orang yang memperkarakan pencegahan terhadap dirinya menempuh upaya hukum ke PTUN. mekanisme perlawanan terhadap pencegahan bakal bertambah karena Rancangan UndangUndang (RUU) Keimigrasian yang sedang digodok memasukkan mekanisme keberatan. Keberatan diajukan kepada pejabat yang mengeluarkan keputusan tata usaha negara. Mekanisme keberatan tersebut diatur dalam pasal 27 RUU Keimigrasian. setiap orang yang dikenai pecegahan dapat mengajukan keberatan kepada pejabat yang mengeluarkan keputusan pencegahan. 
Dalam UU Keimigrasian,mekanisme semacam itu tidak diatur secara tegas. Namun dalam prakteknya, pihak yang dicegah acapkali mengajukan keberatan. Respon pejabat yang mengeluarkan keputusan cegah memang sangat menentukan. Mekanisme keberatan adalah sesuatu yang lumrah ditemukan. Itu seperti upaya banding administratif di lingkungan pemerintahan. Namun, bisa saja pejabat mengabaikan keberatan dari orang yang dicegah, sehingga harus ada peluang untuk menggunakan mekanisme hukum lain.

Selebihnya terkait dengan upaya melawan ataupun mengatasi cekal adalah dengan menunggu daftar cekal berakhir, dan kemudian bisa berpergian. Selama bertahuntahun banyak orang mencoba pendekatan ini dan sayangnya ditolak di perbatasan. Sekarang Anda tahu lebih baik: daftar hitam sementaraseharusnya hanya berlangsung 6 bulan kecuali diperpanjang. Namun, dalam praktiknya pembaruan secara otomatis tanpa batas.

\section{Penutup}

\section{Kesimpulan}

Undang-undang Keimigrasian Nomor 6 tahun 2011 mengatur tentang pencegahan dan penangkalan, yaitu ketentuan yang melarang setiap individu bepergian ke luar wilayah negara Republik Indonesia atau memasuki wilayah Indonesia. Ketentuan ini terutama ditujukan pada pembatasan hak asasi manusia, karena bertentangan dengan prinsip umum yang berlaku di tingkat internasional, yaitu setiap orang berhak bepergian ke luar negeri atau memasuki wilayah suatu negara. Namun, karena ini untuk kepentingan keamanan negara Indonesia dan rakyat Indonesia serta perlindungan hak asasi manusia, maka topik pencegahan dan penangkalan ini dibahas dalam bab tersendiri untuk perlindungan dan kepastian hukum yang lebih baik dalam Undang-undang Imigrasi No. 91992.

Ketentuan

Undang-Undang Keimigrasian yang berkaitan dengan pencegahan dan penangkalan, khususnya pencegahan dan penangkalan terhadap Orang Asing, sejalan dengan kebijakan pemerintah di bidang keimigrasian yang didasarkan pada asas "selective policy",Kebijakan yang didasarkan pada prinsip selektivitas. Menurut prinsip ini, hanya orang asing yang dapat membawa kesejahteraan rakyat, bangsa, dan negara Republik Indonesia yang tidak mengancam keamanan dan ketertiban serta tidak memusuhi rakyat atau negara kesatuan Republik Indonesia yang dapat masuk atau keluar wilayah Indonesia yang berdasarkan pada Pancasila dan Undang-Undang Dasar 1945.

Warga negara asing dapat dilarang untuk sementara waktu memasuki wilayah Negara Kesatuan Republik Indonesia karena alasan tertentu, seperti permusuhan terhadap rakyat dan Negara Kesatuan Republik Indonesia berdasarkan Pancasil dan UndangUndang Dasar 1945.

Asas setiap WNI berhak keluar atau memasuki wilayah negara Republik Indonesia. Namun, bukan berarti hak-hak ini tidak dapat dibatasi. Untuk alasan tertentu dan untuk jangka waktu tertentu, warga negara Indonesia dapat ditolak masuk ke wilayah negara Republik Indonesia. Keputusan untuk penangkalan atau mencegah ini tidak mempengaruhi kemampuan otoritas yang berwenang untuk memberikan wewenang kepada seseorang yang dilarang bepergian ke luar wilayah Republik Indonesia untuk alasan keamanan, ziarah dan nasional.

Karena penangkal terutama ditujukan pada orang asing, penangkal terhadap warga negara Indonesia hanya digunakan dalam keadaan yang sangat khusu. Penangkalan berkenaan dengan Warga Negara Indonesia diberlakukan bagi mereka yang telah lama meninggalkan Indonesia atau yang merupakan penduduk tetap atau penduduk negara lain dan yang telah melakukan tindakan atau sikap permusuhan terhadap negara dan pemerintah Republik Indonesia. Selain itu, tindakan penahanan dapat 
dilakukan terhadap warga sipil Indonesia dengan alasan masuknya mereka ke dalam wilayah Negara Kesatuan Republik Indonesia mengganggu pembangunan nasional, menyebabkan perpecahan nasional dan mengganggu stabilitas nasional serta menibulkan ancaman.

Dalam konteks ini, pelaksanaannya dilakukan dengan sangat hati-hati dan selektif, dengan ketelitian dan ketelitian penuh, baik menyangkut petugas yang bertugas dan bertanggung jawab atas pencegahan atau penangkalan, dengan alasan yang digunakan untuk mencegah atau menghalangi orang. tunduk pada pencegahan atau penahanan dan prosedur pelaksanaannya.

Dalam UU Keimigrasian n.6 tahun 2011, agen yang diberi kewenangan untuk melakukan tindakan preventif atau pencegah berbeda dengan yang berwenang melakukan tindakan jera, baik untuk menghalangi orang asing maupun untuk menghalangi warga negara Indonesia.

\section{DAFTAR PUSTAKA}

Bahri, Imam, Suhaidi, Mahmul Siregar, and Mahmud Mulyadi. "PENGAWASAN KEIMIGRASIAN TERHADAP ORANG ASING DALAM RANGKA PENDEPORTASIAN DITINJAU DARI UNDANG-UNDANG $\begin{array}{llll}\text { NOMOR } & 6 & \text { TAHUN } & 2011\end{array}$ TENTANG KEIMIGRASIAN (STUDI DI KANTOR IMIGRASI KELAS I POLONIA MEDAN)." Journal of Chemical Information and Modeling 53, no. 9 (2013): 16891699.

CCN indonesia. "Tahun 2018, WN China Paling Banyak Ditindak Imigrasi." https://www.cnnindonesia.com/nasio nal/20181213111848-12-

353346/tahun-2018-wn-chinapaling-banyak-ditindak-imigrasi.
Deshinta, Wafia Silvi. "Fungsi Pengawasan Keimigrasian Dalam Pengendalian Radikalisme Pasca Penerapan Kebijakan Bebaas Visa Kunjungan" (2017): 15-28.

Fallis, A.G. "Pengawasan Dan Penindakan Keimigrasian Bagi Orang Asing Yang Melebihi Batas Waktu Izin Tinggal Di Indonesia." Journal of Chemical Information and Modeling 53, no. 9 (2013): 1689-1699.

Fernando, Sam. "Politik Hukum Pemerintah ( Direktorat Jenderal Imigrasi ) Dalam Menanggulangi Masalah Penyelundupan Manusia" (2013): 113.

Hartono, Bambang. "Upaya Penegakan Hukum Terhadap Tindak Pidana Keimigrasian," no. 26 (1992).

Imigrasi, Direktorat Jenderal. "UndangUndang Nomor 6 Tahun 2011 Tentang Keimigrasian ” (2015): 206.

Indonesia, Republik. "Peraturan Pemerintah Republik Indonesia Nomor 30 Tahun 1994 Tentang Tata Cara Pelaksanaan Pencegahan Dan Penangkalan" (1994).

Kementrian Hukum dan HAM. UndangUndang Nomor 6 Tahun 2011 Tentang Keimigrasian. Indonesia, 2011.

Nugroho, Trisapto Agung. "Peran Intelijen Keimigrasian Dalam Rangka Antisipasi Terhadap Potensi Kerawanan Yang Ditimbulkan Oleh Orang Asing Di Wilayah Indonesia." Jurnal Ilmiah Kebijakan Hukum 12, no. 3 (2018): 275. 
Jurnal Sains Riset (JSR)

p-ISSN 2088-0952, e-ISSN 2714-531X

http://journal.unigha.ac.id/index.php/JSR

DOI. 10.47647/jsr.v10i12

Rahardjo, Satjipto. Masalah Penegakan Hukum Suatu Tinjauan Sosiologis. Bandung: CV. Sinar Baru, 2009.

Sumsel, Kanwil. "Fungsi Keimigrasian Adalah Bagian Dari Urusan Pemerintahan Negara Dalam Memberikan Pelayanan Keimigrasian, Penegakan Hukum, Keamanan Negara, Dan Fasilitator Pembangunan Kesejahteraan Masyarakat."

https://sumsel.kemenkumham.go.id/i ndex.php/berita-kanwil/beritautama/3591-fungsi-keimigrasianadalah-bagian-dari-urusanpemerintahan-negara-dalammemberikan-pelayanankeimigrasian-penegakan-hukumkeamanan-negara-dan-fasilitatorpembangunan-kesejahteraan-.

Syahrin, M. Alvi,Imigran Ilegal, Migrasi atau Ekspansi?,Majalah Check Point,Edisi 3 Oktober 2015, Jakarta: Akademi Imigrasi. Syahrin, M. Alvi,Penyadapan oleh Australia, Sebaiknya Imigrasi Bersikap,Majalah Bhumi Pura. Januari-Februari 2014, Jakarta: Direktorat Jenderal Imigasi.

Syahrin, M. Alvi,Eksodus Warga Negara Tiongkok: Antara Kebijakan dan Penyelundupan,Majalah Check Point,Edisi 5 November 2016, Jakarta: Akademi Imigrasi. Syahrin, M. Alvi,Hak Asasi Bermigrasi,Majalah Bhumi Pura, November 2015, Jakarta: Direktorat Jenderal Imigrasi.

“Undang Undang Dasar 1945” (n.d.). 